\title{
Prevalence of eye diseases and refractive errors in children seen at a referral center for ophthalmology in the central-west region, Brazil
}

\author{
Prevalência de doenças oculares e causas de comprometimento \\ visual em crianças atendidas em um Centro de Referência em \\ Oftalmologia do centro-oeste do Brasil
}

Maria Nice Araujo Moraes Rocha'; Marcos Pereira de Ávila ${ }^{1}$; David Leonardo Cruvinel Isaac ${ }^{1}$; Luisa Salles de Moura Mendonça ${ }^{1}$;Liene Nakanishi ${ }^{2}$; Luisa Jácomo Auad ${ }^{3}$

\begin{abstract}
Objective: To identify the levels of visual impairment and prevalence of eye diseases and refractive errors in children seen at a referral center for ophthalmology in the Central-West region compare findings with published data for other regions of Brazil. Methods: Crosssectional, descriptive and retrospective analysis of medical records of children enrolled in the Center of Reference in Ophthalmology Universidade Federal de Goiás, in the period between april 2009 and march 2010. Results: A total of 2408 patient charts, and 2128 (88.4\%) of elective care and $280(11.6 \%)$ of care in the emergency department CEROF. Predominated in the age group 6-10 years (44.2\%), followed by 11-14 years (29.6\%). The examination was normal in $12.9 \%(n=274)$ of elective care and $6.8(n=19)$ of emergency visits. The disease most commonly found in children were infectious conjunctivitis (248 cases, 26.4\%) and allergic (204 cases, 21.7\%), blepharitis (69 cases, 7.3\%), chalazion (34 cases, $3.6 \%$ ), strabismus (133 cases, 12.06\%), diseases of retina and vitreous (24 cases, $2.6 \%)$, cataract and lens changes (20 cases, $2.1 \%$ ). Ametropia frequently told by eye, were hyperopia (46.9\%) and astigmatism (42.2\%) and systemic diseases were more informed prematurity (30 cases) and diabetes mellitus (26 cases). Conclusion: This study identified the main causes of eye diseases in children seen in a university referral center. The group of diseases more prevalent was the disease of the cornea and conjunctiva (allergic conjunctivitis, dry eye and keratitis). Diseases were the second eyelid (blepharitis, chalazion, and lacrimal obstructions). The refractive errors were the most common hyperopia and astigmatism. The findings in the study population are shown similar to those observed in the national literature.
\end{abstract}

Keywords: Visual acuity; Amblyopia; Refractive errors; Strabismus; Eye health; Vision disorders; Child

\footnotetext{
1 University Hospital, Federal University of Goiás, Goiânia/GO, Brazil.

${ }^{2}$ Goiás Eye Bank Foundation, Federal University of Goiás, Goiânia/GO, Brazil.

${ }^{3}$ Petrópolis Medical School, Rio de Janeiro/RJ, Brasil.
}

The authors declare no conflict of interest. 


\section{ReSUMO}

Objetivo: Identificar os níveis de comprometimento visual e a prevalência de oftalmopatias e ametropias em crianças atendidas em um centro de referência em oftalmologia do centro-oeste brasileiro. Comparar os achados com dados publicados referentes a outras regiões do Brasil. Métodos: Estudo transversal, descritivo e retrospectivo com análise de prontuários de crianças atendidas no Centro de Referência em Oftalmologia (CEROF) da Universidade Federal de Goiás, no período compreendido entre abril de 2009 e março de 2010. Resultados: Foram avaliados 2408 prontuários, sendo 2128 (88,4\%) de atendimento eletivo e 280 $(11,6 \%)$ de atendimento no setor de urgências do CEROF. Houve predomínio na faixa etária de 6 a 10 anos (44,2\%), seguido pela de 11 a 14 anos $(29,6 \%)$. O exame foi considerado normal em 12,9\% ( $\mathrm{n}=274)$ dos atendimentos eletivos e em 6,8 $(\mathrm{n}=19)$ dos atendimentos de urgência. As doenças mais encontradas nas crianças foram as conjuntivites infecciosas (248 casos, $26,4 \%$ ) e alérgicas (204 casos, 21,7\%), blefarite (69 casos, 7,3\%), calázio (34 casos, 3,6\%), estrabismo (133 casos, 12,06\%), as doenças de retina e vítreo ( 24 casos, 2,6\%), catarata e alterações de cristalino (20 casos, 2,1\%). As ametropias mais frequentes, contadas por olho, foram a hipermetropia (46,9\%) e o astigmatismo $(42,2 \%)$ e as doenças sistêmicas mais informadas foramprematuridade (30 casos) e diabete melito (26 casos). Conclusão: Este estudo identificou as principais causas de doenças oculares em crianças atendidas em um centro universitário de referência. O grupo de doenças mais prevalente foi o das doenças de córnea e conjuntiva (conjuntivites alérgicas, olho seco e ceratites). As doenças de pálpebra ocuparam o segundo lugar (blefarite, calázio, e obstrução de vias lacrimais). As ametropias mais frequentes foram a hipermetropia e o astigmatismo. Os achados na população estudada mostram-se semelhantes aos observados na literatura nacional.

Descritores: Acuidade visual; Ambliopia; Erros de refração; Estrabismo; Saúde ocular; Transtornos da visão; Criança

\section{INTRODUCTION}

$\mathbf{T}$ The United Nations Children's Fund (UNESCO) defines childhood as the period from birth until 15 years of age.

Every year between 1 and 2 million people, mostly women, become blind worldwide. Around 1.4 million children under 15 years of age are blind. Recent census data show that there are around 54 million children in Brazil (30\% of the population), of which about 32,000 are blind. The number of visually-impaired children (best corrected visual acuity under 0.3 ) is 3 to 4 times higher. According to the World Health Organisation (WHO), about $75 \%$ of causes of blindness can be avoided through preventive or therapeutic measures, regardless of age. Controlling childhood blindness is one of the priorities of the WHO through its programme "VISION 2020: the Right to Sight"1.

About 500,000 children become blind each year worldwide, and $70 \%$ die in the first years of life due to diseases causing visual impairment ${ }^{2}$. Population-based studies show that the prevalence of childhood blindness is lower in developed than in developing countries. According to the WHO, in Brazil the rate of childhood blindness is $0,6 \%$, and in 2004 there were 32.400 blind and 130.000 visually-impaired children in the country ${ }^{3}$.

About $20 \%$ of school-age children have eye disorders of different causes, including biological, social, and environmental factors. Late diagnosis leads to poor school performance and socialisation, which can damage a child's career prospects. The condition can also represent an economic burden for society, warranting initiatives for early diagnosis and treatment ${ }^{4}$. In developed nations, newborn infants undergo routine eye examination due to the existence of policies promoting eye health; in contrast, developing nations often lack the resources to undertake preventive programmes. In Brazil, eye examination is still not performed routinely in children, with visual disorders often being diagnosed only at school age $e^{5,6}$.

The WHO adopted in 1992 the concept of "years of blindness", which is calculated by multiplying the number of years a person lives with blindness (or visual impairment) by the number of blind (or visually-impaired) people to compare the prevalence of different eye disorders. The prevalence of childhood blindness and visual impairment is similar to senile cataract, which affects elderly adults, therefore it should be an ophthalmic public health priority in Latin America?.

According to the literature, the leading causes of visual impairment in children are refractive errors, which can lead to blindness if left untreated, producing a significant economic and psychosocial burden not only in Brazil and Latin America, but also worldwide ${ }^{7}$. Untreated refractive errors are the second leading cause (after cataract) of treatable and preventable blindness. The prevalence of refractive errors in Brazilian school-age children is around $30 \%$, with a predominance of positive refractive errors (hyperopia and hyperopic astigmatism) compared to negative refractive errors (myopia and myopic astigmatism) . $^{8}$.

In a study conducted in the Brazilian town of Petrópolis, Rio de Janeiro, on children aged 0-12 years, refractive errors were the most common $(60.9 \%)$ diagnosis, with hyperopia being the most frequent $(56.88 \%)$ condition followed by astigmatism $(35.31 \%)$ and myopia $(7,81 \%)$. The most prevalent diseases were blepharitis $(40.43 \%)$, conjunctivitis $(27.66 \%)$ and hordeolum $(9.57 \%)$. The frequency of normal eye examinations was $27.61 \%$. Red eye was found in $17.9 \%$, strabismus in $8.57 \%$, amblyopia in $2.58 \%$, pseudostrabismus in $1.52 \%$, lacrimal duct obstruction in $1.33 \%$, conjunctival lesions in $1.14 \%$, retinopathy of prematurity in $0.76 \%$, eye trauma in $0.76 \%$, cataract in $0.57 \%$, ptosis in $0.57 \%$, glaucoma in $0.19 \%$, and other eye disorders in $4.57 \%$. Most children with eye disorders were aged 8-10 years (20.76\%), with a predominance of males $(52.19 \%)^{9}$.

Brazilian studies have found that children represent $16 \%$ to $17.6 \%$ of emergency eye care visits, with a predominance of children under 10 years of age, suggesting that these children are more susceptible to trauma in the home environment ${ }^{10,11}$. According to the National Society to Prevent Blindness (USA), one third of eyes lost in the first decade of life are due to trauma ${ }^{12}$.

This study aimed to investigate the prevalence of the main eye disorders and their degree of visual impairment in children aged 0-14 years seen at the Referral Centre for Ophthalmology 
of the Federal University of Goiás, as no similar studies had been conducted in the region. Studying the epidemiology of eye disorders can be useful in the development of strategies to improve paediatric eye care by contributing to the primary, secondary, and tertiary prevention of eye diseases. Improving eye health policies can not only help reduce the rates of visual impairment, but also decrease the costs of medical care in the state of Goiás and the Central-West region. By studying the eye health status of children in a representative regional sample, we expect to find rates similar to those reported in the national and world literature. If different results are found, this study can then be used as a reference for further research.

\section{MethodS}

Cross-sectional, descriptive, retrospective study based on 2128 medical records of children aged 0-14 years seen at the Referral Centre for Ophthalmology (CEROF) of the Federal University of Goiás between April 2009 and March 2010 (one year). The study was approved by the Ethics Committee on Human and Animal Research (CEPMHA) of the University Hospital of the Federal University of Goiás under file number $039 / 2010$.

The decision to study children under 15 years of age was based on UNICEF's definition of childhood ${ }^{7}$.

The sample included medical records from outpatient and emergency visits. Data collection included socio-demographic data (age and gender) and the following data from ophthalmic examination: external and pupil examination, eye movements, corrected and uncorrected visual acuity, slit lamp biomicroscopy, type of refractive error, fundus examination, and suggested diagnosis. Some patients had more than one diagnosis. The degree of visual impairment (low vision and blindness) was determined based on WHO criteria (visual acuity, visual impairment), as shown in Figure 1.

\begin{tabular}{|l|c|}
\hline Visual impairment & Visual acuity \\
\hline Absent & $\geq 0.3$ and $<1.0$ \\
\hline Low vision Moderate & $\geq 0.1$ and $<0.3$ \\
Severe & $\geq 0.05$ and $<0.1$ \\
\hline Blindness & $<0.05$ or VF $<10^{\circ}$ \\
\hline
\end{tabular}

*Best corrected VA in the best eye

$* * \mathrm{VF}=$ visual field

Figure 1. Classification of visual impairment according to the World Health Organisation

Amblyopia was defined as a corrected visual acuity equal to or lower than $20 / 40$ in the worst eye or a difference of two lines between both eyes in Snellen's chart; anisometropia was defined as a difference of 2 spherical dioptres between both eyes $^{13}$.

In our service, visual acuity testing is not done routinely in children under 3 years of age or those with cognitive conditions preventing them from informing their visual acuity using Snellen's chart (decimal).

Eye conditions were divided into 9 types depending on the affected anatomical region (Figure 2).

\begin{tabular}{|c|c|}
\hline Type & Eye conditions \\
\hline Cornea and conjunctiva & $\begin{array}{l}\text { Infectious and allergic conjunctivitis, dry eye, } \\
\text { keratitis, conjunctival tumour, pterygium, } \\
\text { leukoma. }\end{array}$ \\
\hline Eyelids and lacrimal system & $\begin{array}{l}\text { Blepharitis, chalazion, ptosis, disorders of the } \\
\text { lacrimal system, palpebral tumours, trichiasis. }\end{array}$ \\
\hline Extrinsic ocular muscles & Strabismus, nystagmus. \\
\hline Retina and vitreous & General retinal and vitreous disorders \\
\hline Lens & Cataract \\
\hline Glaucoma & Glaucoma \\
\hline Uveitis & $\begin{array}{l}\text { Anterior and posterior uveitis, toxoplasmosis } \\
\text { uveitis }\end{array}$ \\
\hline Eye globe and orbit & Optic neuritis, bulbar atrophy, orbital tumour \\
\hline Ocular trauma & Lesions due to trauma \\
\hline
\end{tabular}

Figure 2. Types of eye conditions among study participants.

Sample size was determined based on a mathematical model using $p=0,05$, a $5 \%$ level of significance or a $95 \%$ confidence interval, and a $1 \%$ standard estimate of error. The sample included 2128 medical records of children under 15 years of age seen at CEROF between April 2009 and March 2010, corresponding to $30 \%$ of the total number of patients seen at the service during that period. Statistical analysis was done using Microsoft Excel ${ }^{\mathrm{TM}}$ version 7. Data were distributed into categories and the chi-squared test was used to compare categorical variables, with differences showing $\mathrm{p}<0,05$ being considered statistically significant. Differences between genders were calculated using the odds ratio $(\mathrm{OR})$.

\section{RESULTS}

Of the 2408 children included in the study, 2128 (88.4\%) were seen as outpatients and $280(11.6 \%)$ at CEROF's emergency department. Of the 2128 children seen as outpatients, 1129 (53.05\%) were female and $999(46.95 \%)$ were male, while in the emergency department 143 (51.1\%) were female and 137 (48.9\%) were male.

The most common age group was $6-10$ years $(n=1065$, $44.2 \%)$, followed by $11-14$ years $(n=712,29.6 \%), 1-5$ years $(n=464,19.3 \%)$, and $0-1$ year $(n=167,6.9 \%)$. Among outpatient visits, the most common age group was 6-10 years $(n=979$, $46.30 \%)$, followed by $11-14$ years $(n=653,30.7 \%), 1-5$ years $(\mathrm{n}=353,16.6 \%)$, and $0-1$ year $(\mathrm{n}=143,6.7 \%)(\mathrm{p}<0.005)$. Among emergency visits, the most common age group was $1-5$ years $(\mathrm{n}=111,39.6 \%)$, followed by $6-10$ years $(\mathrm{n}=86,30.7 \%), 11-14$ years $(n=59,21.1 \%)$, and $0-1$ year $(n=24,8.6 \%)$. Figure 3 shows the age comparison between outpatient and emergency visits.

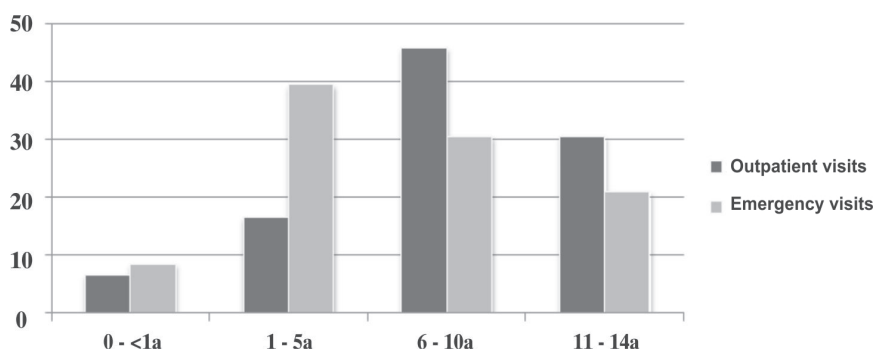

Figure 3. Age distribution in outpatient and emergency visits. 
In total, 932 diseases were diagnosed and classified into 9 groups, including $671(72.0 \%)$ in outpatient visits and 261 $(28.0 \%)$ in emergency visits. The most prevalent conditions were corneal and conjunctival disorders with 550 (59.0\%) cases, followed by disorders of the eyelids and lacrimal system with $158(17.0 \%)$, external ocular muscles (strabismus and nystagmus) with $133(14.3 \%)$, retina and vitreous with 24 $(2.6 \%)$, lens with $20(2.1 \%)$, uveal tract with $17(1.8 \%)$, glaucoma with $16(1.7 \%)$, optic nerve and orbit with $10(1.1 \%)$, and eye trauma with $4(0,4 \%)$ cases. Table 1 shows the distribution of eye disorders found in this study.

Table 1

Distribution of eye disorders diagnosed in outpatient and emergency visits.

\begin{tabular}{|c|c|c|c|}
\hline Diagnosis & $\mathbf{N}$ & $\% 9$ & \%CI Mid-PExact \\
\hline Cornea and conjunctiva & 550 & $\mathbf{5 9 , 0}$ & $(69,68-73,53)$ \\
\hline Infectious conjunctivitis & 248 & 26,6 & $(23,69-29,33)$ \\
\hline Allergic conjunctivitis & 204 & 21,9 & $(19,20-24,48)$ \\
\hline Dry eye & 55 & 5,9 & $(4,49-7,51)$ \\
\hline Keratitis & 24 & 2,6 & $(1,68-3,72)$ \\
\hline Conjuctival tumour & 9 & 1,0 & $(0,47-1,73)$ \\
\hline Pterygium & 6 & 0,6 & $(0,26-1,32)$ \\
\hline Leukoma & 4 & 0,4 & $(0,13-1,02)$ \\
\hline Eyelids and lacrimal system & 158 & 17,0 & $(16,36-19,64)$ \\
\hline Blepharitis & 69 & 7,4 & $(5,81-9,16)$ \\
\hline Chalazion & 34 & 3,6 & $(2,56-4,97)$ \\
\hline $\begin{array}{l}\text { Disorders of the lacrimal } \\
\text { pathways }\end{array}$ & 33 & 3,5 & $(2,47-4,85)$ \\
\hline Ptosis & 9 & 1,0 & $(0,47-1,73)$ \\
\hline Eyelid and orbital tumours & 9 & 1,0 & $(0,47-1,73)$ \\
\hline Trichiasis & 4 & 0,4 & $(0,13-1,02)$ \\
\hline Strabismus & 133 & 14,3 & $(12,06-16,52)$ \\
\hline Retina and vitreous & 24 & 2,6 & $(1,68-3,72)$ \\
\hline Cataract and lens & 20 & 2,1 & $(1,34-3,21)$ \\
\hline Uveitis & 17 & 1,8 & $(1,01-2,69)$ \\
\hline Glaucoma & 16 & 1,7 & $(1,01-2,69)$ \\
\hline Eye globe and orbit & 10 & 1,1 & $(0,54-1,89)$ \\
\hline Eye trauma & 4 & 0,4 & $(0,13-1,02)$ \\
\hline TOTAL & 932 & 100,0 & $(99,49-100,00)$ \\
\hline
\end{tabular}

Overall, 1433 refractive errors were diagnosed, including $672(46.9 \%)$ cases of hyperopia, $605(42.2 \%)$ of astigmatism, and $156(10,9 \%)$ of myopia. Some patients had more than one type of refractive error.

Visual impairment was only assessed in outpatient visits through best corrected visual acuity in the best eye. Results are shown in Table 2.

Visual acuity was not assessed in 388 (18.3\%) patients.
Table 2

Distribution of visual impairment in outpatient visits.

\begin{tabular}{lcc}
\hline \multicolumn{2}{l}{ Visual impairment } & $\begin{array}{c}\text { Visual acuity* } \\
\mathbf{n}(\mathbf{\%})\end{array}$ \\
\hline \multirow{2}{*}{ Absent } & & $1698(98,0)$ \\
Low vision & Moderate & $26(1,5)$ \\
Blindness & Severe & $3(0,2)$ \\
Total & & $5(0,3)$ \\
\end{tabular}

(*) Best corrected VA in the best eye

\section{Discussion}

School screening is important for public and educational health, as many children reach school age without having undergone eye examination. Eye health studies have reported that around $15 \%$ of first-grade children have some visual disturbance, and only $20 \%$ undergo medical follow-up ${ }^{8}$. Ideally, every child should be examined by an ophthalmologist before starting school and should undergo preventive eye examination in the first year of life. In recent years there is increasing awareness of the need for such preventive measures, with campaigns targeted at newborn and school children being used to screen children with eye disorders. Ideally, awareness-raising campaigns on TV, radio, schools, residents' associations, and churches should be used to stimulate prevention and treatment. The Brazilian Society of Paediatric Ophthalmology (SBOP) suggests that children should undergo a complete eye examination performed by an ophthalmologist every 6 months during the first two years of life and then yearly until 79 years of age.

In this study there was a predominance of children aged 610 and 11-14 years, probably due to the important role played by CEROF in providing care to disadvantaged children of school age, which is done in CEROF itself or in school campaigns (such as the "Eye to Eye" campaign) and other campaigns undertaken in different districts of the state capital. Adequate vision in school children is important for adequate learning, while undiagnosed and untreated visual impairment can affect school performance. A significant number of children in this study were aged $0-5$ years, including newborns, infants and pre-school-age children seen as part of screening and prevention initiatives or referred by their paediatricians due to the suspicion of strabismus, allowing visual correction and treatment of amblyopia when necessary. Late treatment or failure to treat children with strabismus and amblyopia worsens the visual prognosis; it should be noted that most cases of amblyopia can be corrected with adequate treatment, while adhesion to and the effectiveness of treatment decrease in children older than 6 years. Among emergency visits there was a predominance of children aged 1-5 and 6-10 years, probably due to the greater incidence of external infection and trauma in these age groups. Awareness-raising campaigns targeting parents and teachers should be used as a preventive and educational measure to prevent accidents in the home environment and educate the public on trauma and infection.

The predominance of disorders of the cornea and conjunctiva can be attributed to the greater diversity of diseases 
in this group, such as infectious conjunctivitis, allergic conjunctivitis, dry eye, and keratitis. These were followed by diseases of the eyelids and lacrimal system due to the higher prevalence of blepharitis, chalazion, and disorders of the lacrimal pathways in children. Strabismus was the third leading disease, and disorders of the retina and vitreous came in fourth place. Cataract had the fifth highest prevalence, followed by glaucoma.

Prevalence data found in this study are similar to previous research on children, with certain differences ${ }^{6,9,12-14}$; for example, only 11 cases of amblyopia were found, which is well below the rates reported on the literature 9 . We believe that the actual number is higher, as the medical records reviewed here only included information on the first ophthalmic visit, while a higher number of cases of the disease were diagnosed in the strabismus department after a complete examination, including corrected visual acuity and binocular vision testing.

The prevalence of refractive errors was $46.9 \%$, of which the most common was hyperopia followed by astigmatism and then myopia. The degree of visual impairment may have been underestimated because visual acuity is not assessed in CEROF in children under 3 years of age.

Our results on refractive errors are similar to previous studies $^{6,9,15}$.

In Brazil, many children are only taken to an ophthalmologist at a late stage, at which point they already have symptoms of low VA or even blindness and the effectiveness of treatment is lower. Media campaigns are needed to inform the population, and paediatricians should be trained to treat the simpler cases and to refer children for routine eye examination with a specialist in order to detect potentially reversible or preventable conditions.

Visual acuity is not assessed routinely in CEROF in children under 3 years of age, and in certain cases the information in medical records was lacking or unreliable, limiting the study results as regards the assessment of visual impairment in outpatient visits. These shortcomings could be overcome by implementing special methods to assess visual acuity and detect amblyopia or changes in binocular vision in pre-verbal and preschool-age children.

\section{Conclusion}

This study identified the leading eye diseases in children under 15 years of age seen in a referral centre for ophthalmology in the city of Goiânia. The prevalence of visual impairment may have been underestimated because visual acuity was not assessed in children under 3 years of age or those with limited communication skills. The types of refractive errors and the sociodemographic profile of the study population (gender, age) were identified for both outpatient and emergency visits. In Brazil, most children reach school age without having been examined by an ophthalmologist, and the failure to prevent, diagnose, and treat preventable and treatable diseases lead to developmental deficits in children and future adults, as well as representing a socioeconomic burden. We hope that this study will help inform local health policy and be used as a reference for further research.
The visual epidemiologic results found in this study were in agreement with the national literature.

\section{RefERENCES}

1. Gilbert C, Foster A. Childhood blindness in the context of VISION 2020 -the right to sight. Bull World Health Organ. 2001;79(3):227-32.

2. Taleb A, Ávila MP, Moreira H. As condições de saúde ocular no Brasil. São Paulo: Conselho Brasileiro de Oftalmologia; 2009.

3. Nakanami C. Cegueira infantil: panorama no Brasil e no mundo[Internet]. São Paulo: Universo visual; 2008 [citado 2013 Set 15]. Disponível em: http://archive-br.com/page/2275592/2013-0611/ http://www.universovisual.com.br/publisher/preview.php? edicao $=0808 \&$ id_mat $=3332$

4. Oliveira CA, HisatomiKS, Leite CP, Schellini AS, Padovani CR, Padovani CRP.Erros de refração como causas de baixa visual em crianças da rede de escolas públicas da regional de Botucatu SP. ArqBras Oftalmol. 2009;72(2):194-8.

5. Beer SM, Scarpi MJ, Minello AA. [Ocular findings in children between 0 and 6 years of age, residing in the city of São Caetano do Sul, SP]. ArqBras Oftalmol. 2003;66(6): 839-45. Portuguese.

6. Couto Júnior AS, Pinto GR,Oliveira DA, HolzmeisterD, Portes AL,NeurauterR, et al. [Prevalence of the ametropiasandeye diseases in preschool and school children of Alto da Boa Vista favelas, Rio de Janeiro, Brazil]. RevBras Oftalmol. 2007;66(5):304-8. Portuguese.

7. Brito PR,Veitzman S. [Causes of blindness and low vision in children]. ArqBras Oftalmol. 2000;63(1):49-54.Portuguese.

8. Gaiotto PC, PassosJúnior W, Schellini AS, Shiratori CA, Padovani CR. [Ocularaffections in 2 to 8 year- old children at Piracicaba city - SP]. Medicina (RibeirãoPreto). 2002;35(4):487-91. Portuguese.

9. Diniz B,Pachá PM. Perfil ocular das crianças atendidas no Serviço de Oftalmologia da Faculdade de Medicina de Petrópolis - RJ. RevBras Oftalmol. 2007;66(1):45-8.

10. Rocha MN, Ávila M, Isaac DL, Oliveira LL, Mendonça LS.Análise das causas de atendimento e prevalência das doenças oculares no serviço de urgência. RevBras Oftalmol.2012:71(6):380-4.

11. Cecchetti DF, Cecchetti SA, Nardy AC, Carvalho SC, Rodrigues ML, Rocha EM. Perfil clínico e epidemiológico das urgências oculares em pronto-socorro de referência. ArqBras Oftalmol. 2008; 71(5):635-8.

12. May DR, Kuhn FP, Morris RE, Witherspoon CD, Danis RP, Matthews GP, et al.Theepidemiology of serious eye injuries from the United States Eye Injury Registry.Graefes Arch ClinExpOphthalmol. 2000;238(2):153-7.

13. Mérula RV,Fernandes LC. [Infantile cataract: the importance of early treatment and diagnosis]. Arq. Bras Oftalmol. 2005;68(3):299-305. Portuguese.

14. Bernardini MC, Nassaralla Junior JJ. [Prevalence of amblyopia in an Ohthalmological Reference Center Goiania city].Arq BrasOftalmol.1999;62(2):169-76. Portuguese.

15. LipenerL,Munoz EH, Moreira JB,Berezovsky A, Salomão SR, Ventura DF. [Refractional astigmatism prevalence and its relationship with grating acuity in children 2 to 36 months of age].Arq BrasOftalmol. 2006;69(3):365-70. Portuguese.

\section{Corresponding author}

CEROF, Universidade Federal de Goiás

Avenida Universitária, 535, Setor Leste Universitário

CEP 74805-050Goiânia/GO, Brazil

Telephone: +5562 32698442

e-mail: clinicarocha@bol.com.br 